\title{
Increasing Eco-Performance of Concrete Blocks through Computational Design Form Optimization
}

\author{
Eugenius Pradipto ${ }^{1}$, Nabila Afif ${ }^{1 *}$ \\ ${ }^{1}$ Department of Architecture and Planning, Faculty of Engineering, Universitas Gadjah Mada \\ *nabilaafif@ugm.ac.id
}

Received: $30^{\text {th }}$ May $2019 \quad$ Final version received:24 ${ }^{\text {th }}$ December 2019

This paper presents creative geometry research focusing on computational design exploration to improve the eco-performance of concrete blocks used as a building material. To provide a positive ecoperformance, an optimized concrete block was designed to be more efficient than a conventional concrete block with respect to the materials used and the space occupied during storage and transport. The results prove that the form is cost-effective and that the environmental impact caused by associated production and distribution processes would be comparatively reduced. Computational research based on parametric design thinking enabled the relationship between form properties as selected design parameters to be evaluated, with the aim of ensuring that efficiency does not compromise technical requirements and that the overall functional role of the concrete block is appropriate when used as a constituent material in nonstructural wall construction. Volumetric-based measurements were employed using Rhinoceros modeling software with a Grasshopper plug-in to assess the eco-performance of the concrete block based on selected indicators. The results show that the folded S-shape concrete block with a width of $40 \mathrm{~mm}$ consumes only $43 \%$ of the main material and $14 \%$ of the auxiliary material relative to a conventional concrete block with a width of $100 \mathrm{~mm}$. When arranged horizontally, a standard container can hold $60 \%$ more of the optimized concrete block units compared to conventional ones. Additional findings were also made that suggest future research potential, including use of the concrete blocks as building elements in passive design strategies.

Keywords: Concrete block, Eco-performance, Form optimization, Parametric design

\section{INTRODUCTION}

1.1. Concrete blocks as building materials

Concrete blocks are one of the most widely used prefabricated building materials globally. They comprise a proportional mixture of paste and aggregates that bond, harden, and gain strength through hydration (Müller et al., 2006). Their pastes and aggregates have similar compositions to other concrete-based products, and the only difference lies in the smaller size of gravel used as the constituent aggregate material. Fine gravel is necessary to produce high-density concrete blocks.

Concrete blocks are a popular building material choice in Indonesia, as they are cheap and relatively easy to obtain (Anggreni et al., 2015). Compared to clay bricks, they are often considered to be more eco-friendly, as they do not require firing treatment during the production process (Mallisa, 2011). However, many studies have revealed the damaging environmental impacts of industrial cement production (IEA \& WBCSD, 2009) and exploitative sand minding (Harlan, 2011; Marini et al., 2014; Dan Gavriletea, 2017). Therefore, regardless of the production process employed, there are environmental issues associated with the production and use of concrete blocks.

\subsection{Research trend}

As the environmental impact of concrete production and its use have become apparent, research trends are increasingly focusing on producing eco-efficient concrete. From a materials approach, studies have been conducted with the aim of partly substituting the main concrete block materials with other materials, including waste material (Liang \& Nusryamsi, 2017; Safinia \& Alkalbani, 2016; Winarno \& Pujantara, 2015). Nevertheless, most of these prototype-scale studies have focused only on the relationship between various mix ratios and conducting a compressive strength analysis of 
concrete blocks, without conducting any further investigations into the correlation between findings and their environmental impacts.

In addition, a growing number of studies have focused solely on establishing an eco-efficiency index or a concrete assessment method based on a selection of interrelated indicators (Hamid \& Shafiq, 2016; Kim et al., 2016; Kobayashi et al., 2005). However, such assessment methods are not directly applicable to the findings of material research. Indices for the assessments were based on large industry-scale concrete production, where various databases (for example those related to social and environmental indicators (Kono et al., 2018)) are available to conduct a comprehensive assessment, whereas these are not available with respect to prototype-scale research. It is thus clear that the gap between studies based on experimental concrete block prototypes and those on industrial-scale concrete eco-assessments needs to be bridged.

\subsection{Research aims}

Departing from a design perspective, this research aims to improve the eco-performance of a concrete block as a building material by optimizing its form via creative computational geometry exploration. Here, the eco-performance is defined as the process of accomplishing a function with full consciousness not only of the function, but also of its economical, technical, and environmental consequences. In this context, the eco-performance of the concrete block relates to its ability to support its own weight within a nonstructural wall at an effective cost, while adhering to technical requirements and causing a minimal environment impact. Through an exploration of the concrete block's geometry, its form is utilized as a practical tool to optimize its eco-performance as a single unit and as a collection of arranged entities in the construction of a wall. In practice, the results can be assessed efficiently using a selection of eco-efficient indicators, regardless of the scale of concrete block production or the material mixture employed.

\subsection{Research scope and limitations}

This research was conducted with the aim of improving the eco-value of concrete as a building material, and in particular, to make a contribution to research on optimizing form (which fewer studies have focused on). In this respect, the functional aspect of a concrete block's eco-performance was limited to its application when constructing a nonstructural wall.

To provide a basis to enable quantification of economical, technical, and environmental effects, several eco-performance indicators were predetermined based on one basic circumstance: their assessment ability using volumetric measurements. The ultimate eco-performance related to the following: (1) the volume of main material used, (2) the volume of auxiliary material used, (3) the block's horizontal storage efficiency, and (4) the block's transport storage efficiency.

\section{MATERIALS AND METHODS 2.1. Geometry exploration as a research strategy}

Recent research trends have shown the wide potential of geometry exploration as a research strategy, not only for generating new shapes, but also to enable the innovative optimization of established concepts. For example, architectural geometry can be employed to analyze complex building structures (Davis et al., 2012), or used in form-finding and pattern analyzes to optimize the structural shape of fabrics (Linthout, 2016), or a combination of shape optimization techniques and nonlinear finite element analysis can be used to analyze tensioned fabric membrane structures (Dinh et al., 2016).

With respect to environmentally driven research, many studies have investigated the relationship between various building forms and their environmental performances, and the largest focus has been on the impact of building form with respect to its thermal performance and energy consumption (Rashdi \& Embi, 2016; Ratti et al., 2003; Zhang et al., 2017). Considering the high concern of current researches to this area of study, detailed case studies related to the aforementioned topics could be expanded largely; from open spaces (Yung et al., 2018) to retrofitted green buildings (Mohd-Rahim et al., 2017).

One of the reasons that this issue has attracted a considerable amount of research, is that building geometry is the only building element that undergoes relatively small changes during a building's life cycle (Zhang et al., 2017). However, despite the large number of studies conducted, most have focused on external 
building components, such as shading devices (Hariyadi et al., 2017), double skin façades (Hariyadi et al., 2015), or even ventilation blocks (Nordin et al., 2019), and only a few studies have focused on the impact of geometry on the scale of internal building elements (such as the concrete block) when a group of such elements are assembled together (for example in wall construction, which represents a large proportion of both the internal and external skin of a building).

Therefore in this research, geometry was explored to optimize an internal building element: the conventional concrete block. Exploration in this respect means that the basic geometry of the concrete block was analyzed thoroughly prior to being deconstructed into several design parameters. These design parameters were then modified repeatedly within a certain constraint, and then analyzed based on the impact that each iteration had on the overall eco-performance of the material. The entire research process was conducted computationally based on a parametric design using Rhinoceros modeling software with a Grasshopper plug-in.

\subsection{Computational design optimization}

Optimization is a process used to generate the best result in the most practical way by utilizing a system that prevents the sole use of experience, intuition, or luck during the process. In the design realm, it comprises several stages as follows: (1) input, where the initial design, optimization goal, and constraint are set; (2) analysis, where the relationships between input and output are defined; and (3) the optimization process, where the intelligence adjusts the best correlation between design constraints and performance through a series of optimization loops (Messac, 2015).

During the last phase, the system plays an important role in maintaining its effectiveness. In a conventional optimization setting, this last phase largely depends on the sole thinking capability of the designer, which can result in a limited number of optimization loops. In such a case, therefore, computation-based optimization can significantly improve the effectiveness of the process, as the computer rapidly processes data. Numerical optimization is an inseparable part of research when conducting design optimization (Pottmann et al., 2015). Thus, a computational design approach based on parametric design thinking was considered appropriate for use in this study, due to its comprehensive use of geometric and numerical logic. Moreover, it can also accommodate a semi-automated optimization loop, where it is possible to isolate a certain part of the process and conduct a separate sub-optimization process. Hence, full recalculation is not necessary whenever local changes are made, and valuable processing time and resources can be managed more efficiently.

\subsection{Design parameters}

In this research, form is defined as the physical features (including unit measurements, dimensions, and joint details) that work together to influence the overall form of the concrete block and contribute to its volumetric quantification. Following this understanding, design parameters were defined as the aforementioned physical features and their associated variables. To maintain a sense of similarity between the optimized and the current form of concrete block, it was important to carefully select which form of parameters were to be preserved and modified within a certain constraint.

Form optimization of a conventional concrete block was then conducted on a unit scale, with careful consideration of its physical connectivity with other concrete blocks when used in wall construction. A conventional concrete block was defined as a three-dimensional rectangular concrete block measuring $400 \times 100 \times 200 \mathrm{~mm}$ in length, width, and height, respectively. It also had a continuous notch on its four sides, which was designed to be filled with cement paste as the binding material, as seen in Figure 1.
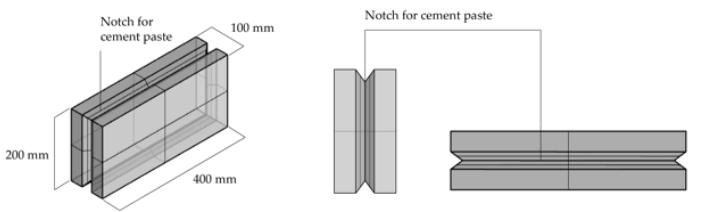

Figure 1: Conventional concrete block (a) isometric view; (b) side view; (c) top view

\subsection{Eco-efficient performance}

Eco-performance is defined as an action or a process used to accomplish a function with full consciousness, not only of the function itself, but also of its economic and environmental impact. Although a large number of aspects contribute to 
a comprehensive understanding and assessment of eco-performance, only several factors were included as assessment criteria in this paper, as presented in Table 1.

Table 1. Eco-performance assessment criteria

\begin{tabular}{|c|c|c|c|c|}
\hline \multirow{2}{*}{ No } & \multirow{2}{*}{$\begin{array}{l}\text { Efficiency } \\
\text { Subject }\end{array}$} & \multicolumn{3}{|c|}{ Eco-Performance Factor } \\
\hline & & Economic & Technical & Environmental \\
\hline 1 & $\begin{array}{c}\text { Main } \\
\text { material }\end{array}$ & $\begin{array}{l}\text { Cost of } \\
\text { material } \\
\text { per unit }\end{array}$ & $\begin{array}{l}\text { Amount } \\
\text { of } \\
\text { material } \\
\text { to be } \\
\text { processed }\end{array}$ & $\begin{array}{c}\text { Exploitative } \\
\text { sand mining } \\
\text { Cement } \\
\text { production } \\
\text { and embodied } \\
\text { energy use }\end{array}$ \\
\hline 2 & $\begin{array}{l}\text { Auxiliary } \\
\text { material }\end{array}$ & $\begin{array}{l}\text { Cost of } \\
\text { material } \\
\text { per unit }\end{array}$ & $\begin{array}{l}\text { Amount } \\
\text { of } \\
\text { material } \\
\text { to be } \\
\text { processed }\end{array}$ & $\begin{array}{l}\text { Exploitative } \\
\text { sand mining } \\
\text { Cement } \\
\text { production } \\
\text { and embodied } \\
\text { energy use }\end{array}$ \\
\hline 3 & $\begin{array}{l}\text { Horizontal } \\
\text { storage } \\
\text { efficiency }\end{array}$ & $\begin{array}{l}\text { Storage } \\
\text { rental fee }\end{array}$ & - & - \\
\hline 4 & $\begin{array}{l}\text { Transportat } \\
\text { ion storage } \\
\text { efficiency }\end{array}$ & $\begin{array}{l}\text { Container } \\
\text { rental fee }\end{array}$ & $\begin{array}{l}\text { Loading } \\
\text { time (in } \\
\text { relation to } \\
\text { unit } \\
\text { height) }\end{array}$ & $\begin{array}{c}\text { Fossil fuel } \\
\text { consumption }\end{array}$ \\
\hline
\end{tabular}

\section{DESIGN PROCESS}

\subsection{Form optimization on unit scale}

The form optimization process was conducted through a series of sequential explorative design steps based on a parametric design thinking, as presented in Figure 2.

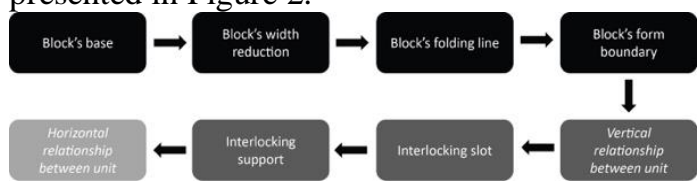

Figure 2: Sequential steps used in design exploration during form optimization process

By conducting the exploration using a modeling interface that supports parametric design thinking, in this case Rhinoceros with Grasshopper plug-in, the entire process was broken down into a series of steps that were executed partly for a local sub-optimization process. In this way, consequential connections between each design parameter in each design step were immediately defined, and these are presented in the following sub-sections.

\subsubsection{Base of block}

Base identification served as a guideline for maintaining similarity between the conventional and optimized concrete blocks. Based on two- dimensional measurements of the base of a conventional concrete block, a rectangular plane measuring $400 \mathrm{~mm} \times 100 \mathrm{~mm}$ was created. The $1^{\text {st }}$ design parameter was a certain odd number that divided the plane into several equally smaller areas, as presented in Figure 3.

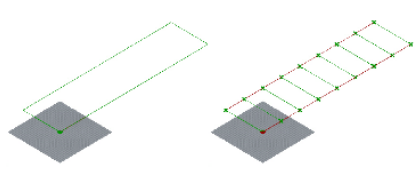

Figure 3: Block base identification process

\subsubsection{Width reduction of block}

The $2^{\text {nd }}$ design parameter related to a width reduction, which increased the economic, technical, and environmental eco-efficiency of the concrete block. During the optimization loop, this parameter was sequentially modified 10 times (ranging from 100 to $10 \mathrm{~mm}$ ), and a series of results from the design optimization simulation tests are presented in Table 2.

Table 2. Block width as design parameter

\begin{tabular}{ccc}
\hline $\begin{array}{c}\text { Test } \\
\text { No }\end{array}$ & $\begin{array}{c}\text { Width } \\
(\mathbf{m m})\end{array}$ & Details \\
\hline 1 & 100 & $\begin{array}{c}\text { Maximum width = width of } \\
\text { conventional concrete block }\end{array}$ \\
2 & 90 & - \\
3 & 80 & - \\
4 & 70 & - \\
5 & 60 & - \\
6 & 50 & $50 \%$ width \\
7 & 40 & - \\
8 & 30 & - \\
9 & 20 & Minimum width set by \\
10 & 10 & author \\
\hline
\end{tabular}

\subsubsection{Folding line of block}

Following the reduction in width, the new thinner block could be folded to increase its stiffness and stability. The folding line was formed by moving two reference points extracted from the lines created in the first design stage to the opposite direction along the y-axis. The amount of this displacement was the $3^{\text {rd }}$ design parameter. An interpolated curve was then constructed by connecting these final points, which afterwards served as the $4^{\text {th }}$ design parameter, and the degree of freedom was an odd number, which influenced the overall shape of the curve. As seen in Figure 4, in all simulations conducted in this study the degree of freedom 
was set as 3 to enable generation of a smooth $\mathrm{S}$ shape curve.

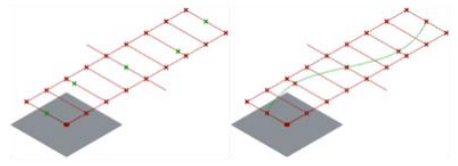

Figure 4: Smooth S-shape curve used as block folding line reference

The S-shape curve was selected because it poses a lower risk of having production defects compared to a fragmented curve. The presence of fragments and sharp edges in a concrete block are prone to production defects, and thus require a higher production skill degree, which also increases production costs and time.

\subsubsection{Formed boundaries of block}

The newly formed boundaries of the concrete block were set by constructing two sets of coupling parallel curves. The first set of the two curves were formed by offsetting the folding curve by a certain number along the y-axis in two opposite directions. This number was obtained by dividing the $2^{\text {nd }}$ design parameter (the optimized width of the block) by two. The second set of curves was then formed by connecting the end points of the two curves from the previous set. The boundary for the optimized concrete block is presented in Figure 5.

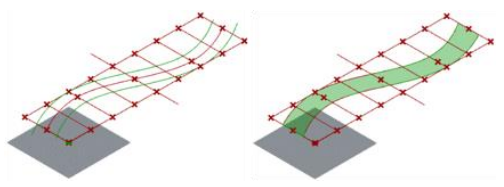

Figure 5: Smooth S-shape curve for block folding line reference

\subsubsection{Vertical relationship between units: interlocking slot}

It is crucial to determine the vertical and horizontal relationships between units when constructing a wall. Considering the curvy form of the optimized block and its reduced width, the interlocking method was the most practical strategy that could be used to vertically connect the blocks. The interlocking point was designed by superimposing two blocks with opposite directions, to obtain a printed position and the dimension of the surface area at the point where the edges of the blocks would meet when arranged horizontally, as seen in Figure 6 (a). To provide a slot for the stacked blocks to overlap, the block's height on the surface area was then reduced, as shown in Figure 6 (b). The $5^{\text {th }}$ parameter was thus the amount of height reduction employed on both the upper and lower sides of the block. Finally, the slot was placed in offset along the longer side of the block to provide a space for the cement paste, which is used as the binding material, as shown in Figure 6 (c). The $6^{\text {th }}$ design parameter was the amount of this offset.

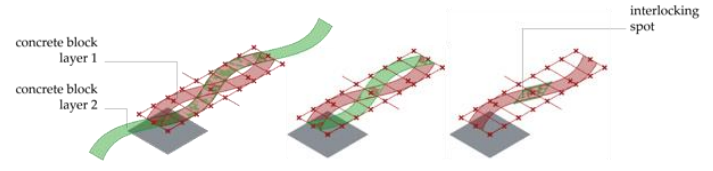

(a) Area where overlapping blocks connect

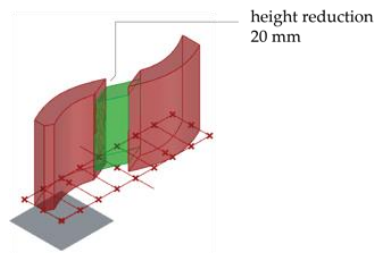

(b) Height reduction of interlocking slot

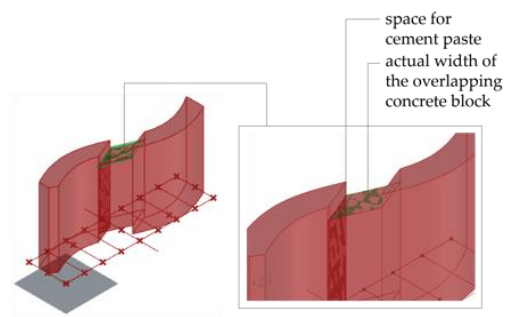

(c) Space for cement paste as binding material on interlocking point.

Figure 6: Vertical relationship between units

\subsubsection{Interlocking support}

With respect to the reduced surface dimension, an additional structure was added; this comprised three-dimensional arches placed on both sides of the interlocking slot to support the load transfer on the interlocking point from the upper to the lower part of the optimized concrete blocks. The base of each arch was constructed using three reference points, as seen in Figure 7 (a), and the $7^{\text {th }}$ parameter was the amount that the second point was displaced along the y-axis. This parameter determines the thickness of the supporting structure, as shown in Figure 7 (b). The $8^{\text {th }}$ design parameter was the height of the structure. The final results of this stage are shown in Figure 7 (c). 


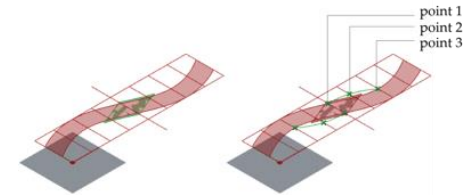

(a) Reference points

$$
\begin{aligned}
& \text { arch width at } \\
& \text { the apex: } 15 \mathrm{~mm}
\end{aligned}
$$

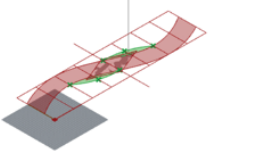

(b) Thickness of support

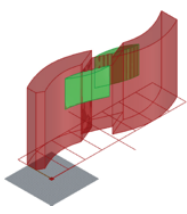

(c) Position of support

Figure 7: Interlocking support

\subsubsection{Horizontal relationship between units}

Similar to the vertical arrangement, the horizontal arrangement of optimized concrete blocks was also secured using a layer of cement paste as the binding material. Unlike with conventional concrete block design, the cement paste was placed in the shape of a near equilateral triangular prism along only one corner on one side of the optimized block, as shown in Figure 8 . The $9^{\text {th }}$ parameter was therefore the length of the sides of the triangles comprising the triangular prism.
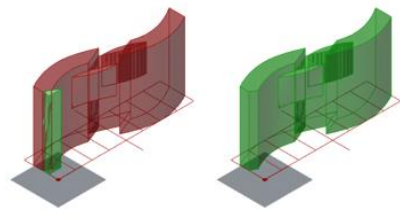

Figure 8: Cement paste space on one corner of block

The design parameters used in forming the optimized concrete block are listed in Table 3, and the sequential relationship between each design parameter is presented in the Figure 9.
Table 3. Design parameters utilized in this research

\begin{tabular}{|c|c|c|c|c|}
\hline \multirow[b]{2}{*}{ No } & \multirow{2}{*}{$\begin{array}{c}\text { Related } \\
\text { component }\end{array}$} & \multicolumn{2}{|c|}{ Constraint } & \multirow{2}{*}{$\begin{array}{l}\text { Input } \\
\text { number }\end{array}$} \\
\hline & & $\begin{array}{l}\text { Min. } \\
\text { value }\end{array}$ & $\begin{array}{l}\text { Max. } \\
\text { value }\end{array}$ & \\
\hline 1 & $\begin{array}{c}\text { Division of } \\
\text { block }\end{array}$ & 1 & - & 8 \\
\hline 2 & $\begin{array}{l}\text { With of } \\
\text { block }\end{array}$ & $10 \mathrm{~mm}$ & $\begin{array}{l}100 \\
\mathrm{~mm}\end{array}$ & $\begin{array}{c}10,20, \\
30,40, \\
50,60, \\
70,80, \\
90,100 \\
\mathrm{~mm}\end{array}$ \\
\hline 3 & $\begin{array}{c}\text { Folding line } \\
\text { of block }\end{array}$ & 0 & $\begin{array}{c}0.5 \times \\
w^{*}\end{array}$ & $\begin{array}{c}0.25 \times \\
\mathrm{W}\end{array}$ \\
\hline 4 & $\begin{array}{c}\text { Folding line } \\
\text { of block }\end{array}$ & $\begin{array}{c}1 \\
\text { (fragmented) }\end{array}$ & $\begin{array}{c}3 \\
\text { (smooth) }\end{array}$ & 3 \\
\hline 5 & $\begin{array}{c}\text { Interlocking } \\
\text { slot }\end{array}$ & 0 & $\begin{array}{c}10 \\
\mathrm{~mm}\end{array}$ & $5 \mathrm{~mm}$ \\
\hline 6 & $\begin{array}{c}\text { Interlocking } \\
\text { slot }\end{array}$ & 0 & $\begin{array}{c}0.5 \times \\
\mathrm{W}\end{array}$ & $0.2 \times w$ \\
\hline 7 & $\begin{array}{c}\text { Interlocking } \\
\text { support }\end{array}$ & 0 & $\begin{array}{c}100- \\
\mathrm{w}\end{array}$ & $15 \mathrm{~mm}$ \\
\hline 8 & $\begin{array}{c}\text { Interlocking } \\
\text { support }\end{array}$ & 0 & $\mathrm{~h}$ & $\begin{array}{c}0.5 \times \\
\mathrm{h}^{* *}\end{array}$ \\
\hline 9 & $\begin{array}{l}\text { Horizontal } \\
\text { binding } \\
\text { system }\end{array}$ & 0 & $\mathrm{~h}$ & $20 \mathrm{~mm}$ \\
\hline
\end{tabular}

$* \mathrm{w}=$ width of conventional concrete block

$* * \mathrm{~h}=$ height of conventional concrete block

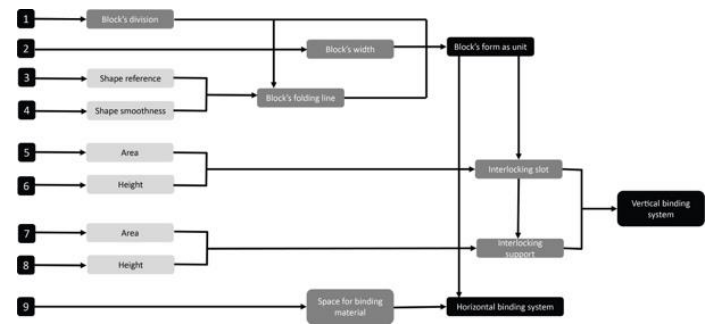

Figure 9: Sequential relationships between design parameters

\section{RESULTS AND DISCUSSION 4.1. Horizontal relationship between units}

In this research, 10 simulation tests were conducted under $10 \%$ sequential block width reductions (with the same S-shape). The block width in the first test was set as the width of conventional concrete block $(100 \mathrm{~mm})$ and the final test was set as $10 \mathrm{~mm}$. The results are presented in Table 4. 
Table 4. Series of optimization tests with $10 \%$ sequential block width reductions

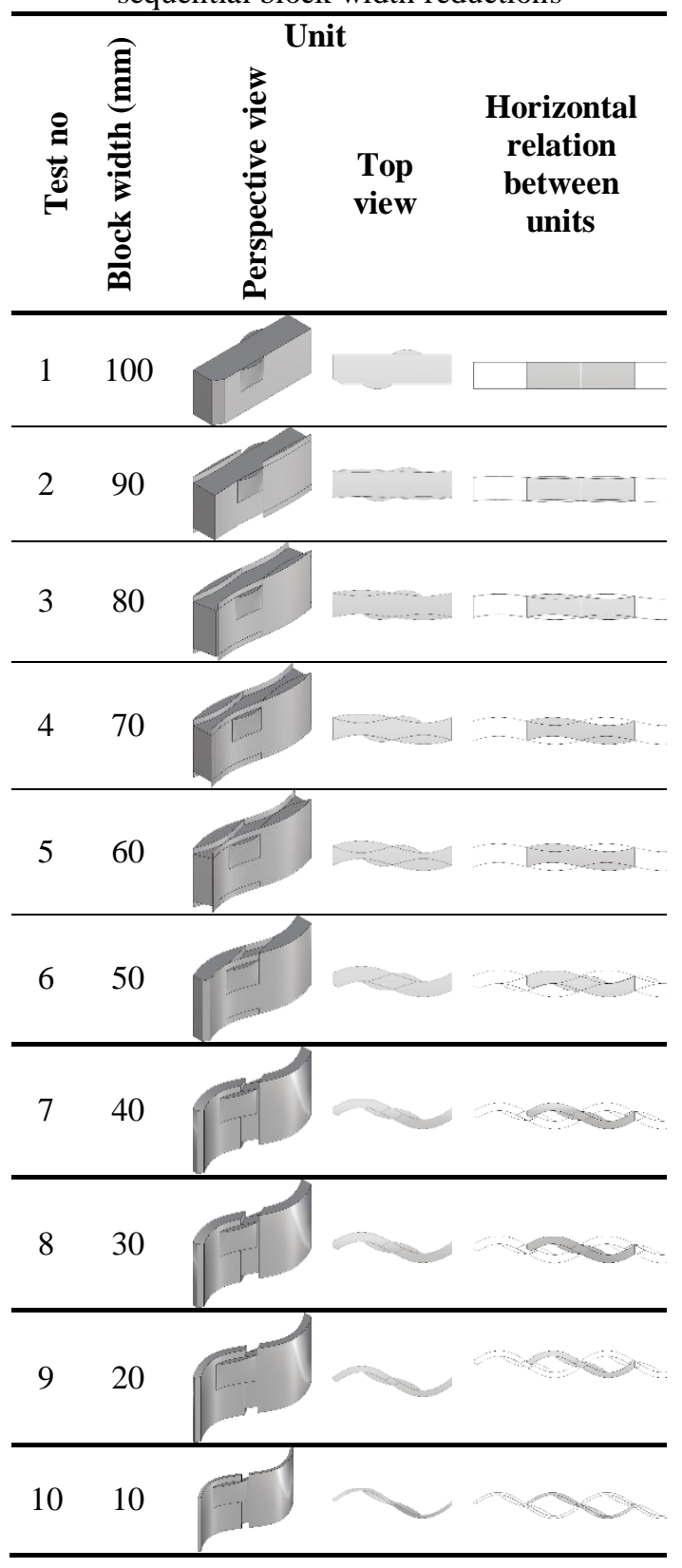

Based on the test results, a preliminary decision was made to partly eliminate several of the results that were inadequate with respect to the interlocking connection, and their production was considered impractical (test numbers 1 to 5). The width ranges of these blocks would be impractical when stacked vertically, as they would create an oversized overlapping area that would lead to an overly large interlocking cut, as shown in Table 5.
Table 5. Test numbers 1 to 5 resulted in oversized area for interlocking support

\begin{tabular}{ccc}
\hline $\begin{array}{c}\text { Test } \\
\text { number }\end{array}$ & $\begin{array}{c}\text { Block width } \\
(\mathbf{m m})\end{array}$ & $\begin{array}{c}\text { Interlocking } \\
\text { area }\end{array}$ \\
\hline 1 & 100 & \\
\hline 2 & 90 \\
\hline 4 & 80 \\
\hline 5 & 70 \\
\hline
\end{tabular}

Test number 6 was also eliminated because the interlocking spot was oversized in relation to the presence of the $5 \mathrm{~mm}$ offset on the interlocking spot. The presence of adequate offset space for cement is vital to support the vertical connection between each concrete blocks, while an oversized interlocking spot is impractical: therefore its size cannot be compromised. Only test results numbers 7-10 were subsequently evaluated based on the predetermined ecoperformance indicators including: (1) volumetric consumption of main material, (2) volumetric consumption of auxiliary material, (3) horizontal storage efficiency, and (4) transport storage efficiency. Every test result was measured and compared with that of a conventional concrete block (on the data base).

\subsection{Volumetric ratio of optimized form in unit scale}

A sequential block width decrease of $10 \mathrm{~mm}$ resulted in a linear sequential decrease of approximately $10 \%$ of the overall volume of the optimized concrete block, as shown in Table 6 . 
Table 6. Relationship between block width, total volume, and volumetric consumption of main

\begin{tabular}{|c|c|c|c|}
\hline \multirow[b]{2}{*}{$\begin{array}{l}\text { Test } \\
\text { No. }\end{array}$} & \multicolumn{3}{|c|}{ Block unit } \\
\hline & $\begin{array}{l}\text { Width } \\
\text { (mm) }\end{array}$ & $\begin{array}{c}\text { Total } \\
\text { volume } \\
\left(\mathbf{m m}^{3}\right)\end{array}$ & $\begin{array}{c}\text { Volumetric } \\
\text { consumption } \\
\text { of main } \\
\text { material } \\
(\%)\end{array}$ \\
\hline 1 & $\begin{array}{c}100 \\
\text { (base) }\end{array}$ & $7,656,000$ & $100 \%$ \\
\hline 7 & 40 & $3,308,700$ & $43 \%$ \\
\hline 8 & 30 & $2,564,600$ & $33 \%$ \\
\hline 9 & 20 & $1,773,500$ & $23 \%$ \\
\hline 10 & 10 & 940,071 & $12 \%$ \\
\hline
\end{tabular}

As the width of the block was sequentially reduced by $10 \mathrm{~mm}$, there was also a sequential reduction in the total cement paste volume of $2 \%$, as shown in Table 7.

Table 7. Relationship between width of block and detailed volumetric consumption of auxiliary material

\begin{tabular}{|c|c|c|c|}
\hline \multirow[b]{2}{*}{$\begin{array}{l}\text { Test } \\
\text { No. }\end{array}$} & \multicolumn{3}{|c|}{ Cement paste } \\
\hline & $\begin{array}{l}\text { Width } \\
\text { (mm) }\end{array}$ & $\begin{array}{c}\text { Total } \\
\text { volume } \\
\left(\mathbf{m m}^{3}\right)\end{array}$ & $\begin{array}{c}\text { Volumetric } \\
\text { consumption } \\
\text { of main } \\
\text { material } \\
(\%)\end{array}$ \\
\hline 1 & $\begin{array}{c}100 \\
\text { (base) }\end{array}$ & 344,004 & $100 \%$ \\
\hline 7 & 40 & 48,439 & $14 \%$ \\
\hline 8 & 30 & 40,266 & $12 \%$ \\
\hline 9 & 20 & 34,345 & $10 \%$ \\
\hline 10 & 10 & 26,763 & $8 \%$ \\
\hline
\end{tabular}

In addition, the decrease in the width of the block resulted in a gradual increase in the horizontal storage efficiency. The measurement for storage was set as $1.000 \times 400 \times 200 \mathrm{~mm}$ for a single row of concrete blocks arranged horizontally. This dimension was chosen to generate basic data, as it could then be multiplied by any number depending on the desired storage dimension. The results of these measurements are shown in Table 8.
Table 8. Relationship between width of block and detailed volumetric efficiency of horizontal storage and transport capacity

\begin{tabular}{cccc}
\hline \multirow{2}{*}{$\begin{array}{c}\text { Test } \\
\text { No. }\end{array}$} & $\begin{array}{c}\text { Block } \\
\text { unit }\end{array}$ & \multicolumn{2}{c}{$\begin{array}{c}\text { Horizontal storage/ } \\
\text { Transportation }\end{array}$} \\
\cline { 2 - 4 } & $\begin{array}{c}\text { Width } \\
\text { (mm) }\end{array}$ & $\begin{array}{c}\text { Total } \\
\text { capacity } \\
\text { (unit) }\end{array}$ & $\begin{array}{c}\text { Storage/ } \\
\text { Transportation } \\
\text { capacity ratio } \\
(\%)\end{array}$ \\
\hline 1 & 100 & 10 & $100 \%$ \\
7 & 40 & 16 & $160 \%$ \\
8 & 30 & 19 & $190 \%$ \\
9 & 20 & 25 & $250 \%$ \\
10 & 10 & 33 & $330 \%$ \\
\hline
\end{tabular}

As the optimized concrete block was used at the same height as the conventional one, measurements of its vertical storage efficiency were assumed to be irrelevant. With respect to transportation efficiency, concrete blocks are usually transported using a container; therefore, in this research, the blocks within the container were assumed to be arranged in a similar manner (horizontally stored). The calculation presented in Table 8 is thus also applicable for measuring the transportation efficiency.

\begin{tabular}{|c|c|c|c|c|}
\hline \multirow{2}{*}{$\begin{array}{l}\text { Test } \\
\text { No. }\end{array}$} & \multirow{2}{*}{$\begin{array}{c}\text { Block } \\
\text { unit } \\
\text { width } \\
(\mathbf{m m})\end{array}$} & \multicolumn{2}{|c|}{$\begin{array}{c}\text { Cement paste volume } \\
\left(\mathrm{mm}^{3}\right)\end{array}$} & \multirow{2}{*}{$\begin{array}{c}\text { Volumetric } \\
\text { consumption } \\
\text { ratio }(\%)\end{array}$} \\
\hline & & On edge & $\begin{array}{c}\text { On } \\
\text { interlocking } \\
\text { slot }\end{array}$ & \\
\hline 1 & $\begin{array}{c}100 \\
\text { (base) }\end{array}$ & 344004 & 0 & $100 \%$ \\
\hline 7 & 40 & 34220 & 14219 & $14 \%$ \\
\hline 8 & 30 & 31565 & 8701 & $12 \%$ \\
\hline 9 & 20 & 29365 & 4980 & $10 \%$ \\
\hline 10 & 10 & 24536 & 2227 & $8 \%$ \\
\hline
\end{tabular}

\subsection{Additional findings}

In addition to the findings relating to predetermined eco-performance indicators, the test results were further analyzed to generate a more comprehensive assessment of the use of the optimized concrete block as a building material. Among the additional findings were: (1) the relationship between the width of the block and the volumetric measurement of the block resting on the interlocking slot, as presented in Table 9; and (2) the relationship between the width of the block and the weaved gap width, as presented in Table 10. 
Table 9. Relationship between width of block and detailed volumetric measurement of interlocking slot

\begin{tabular}{|c|c|c|c|c|}
\hline \multirow{2}{*}{$\begin{array}{l}\text { Test } \\
\text { No. }\end{array}$} & \multicolumn{2}{|c|}{ Block unit } & \multirow{2}{*}{$\begin{array}{c}\begin{array}{c}\text { Block resting } \\
\text { on } \\
\text { interlocking } \\
\text { slot }\end{array} \\
\begin{array}{c}\text { Proportional } \\
\text { volume }\end{array} \\
\end{array}$} & \multirow{2}{*}{$\begin{array}{c}\begin{array}{c}\text { Additional } \\
\text { support }\end{array} \\
\begin{array}{c}\text { Volume } \\
\left(\mathrm{mm}^{3}\right)\end{array} \\
\end{array}$} \\
\hline & $\begin{array}{l}\begin{array}{l}\text { Width } \\
(\mathbf{m m})\end{array} \\
\end{array}$ & $\begin{array}{c}\begin{array}{l}\text { Volume } \\
\left(\mathbf{m m}^{3}\right)\end{array} \\
\end{array}$ & & \\
\hline 1 & 100 & 7656000 & - & 0 \\
\hline 7 & 40 & 3308700 & $1.15 \%$ & 39934 \\
\hline 8 & 30 & 2564600 & $0.69 \%$ & 39953 \\
\hline 9 & 20 & 1773500 & $0.32 \%$ & 39941 \\
\hline 10 & 10 & 940071 & $0.11 \%$ & 39901 \\
\hline
\end{tabular}

It can be seen from Table 9 that a decrease in the width of the block results in a decrease in the areas of the interlocking slot. Consequently, the volume of the edges of the two blocks put on the interlocking slot is also decreased (a larger volume indicates that a greater portion of the overlapping blocks is necessary to obtain better connectivity between each concrete block unit when constructing a wall). Furthermore, when the blocks are arranged vertically, weaved gaps are formed in relation to two of the design decisions: (1) using the S-shape interpolated curve as a form guiding line, and (2) the position of the overlapping concrete blocks on interlocking areas. It is evident from Table 10 that different block widths result in different weaved gap widths.

Table 10. Test numbers 1 to 5 show evident differences between weave gap widths

\begin{tabular}{ccc}
\hline $\begin{array}{c}\text { Test } \\
\text { number }\end{array}$ & $\begin{array}{c}\text { Block } \\
\text { width } \\
(\mathbf{m m})\end{array}$ & Weaved gaps \\
\hline 7 & 40 & \\
\hline 8 & 30 \\
\hline 9 & 20 \\
\hline 10 & 10 \\
\hline
\end{tabular}

It can be seen from the simulation test results that a sequential decrease in the block's width of $10 \mathrm{~mm}$ resulted in a linear increase in the width of the weaved gap of $20 \mathrm{~mm}$, as shown in Table 11.
Table 11. Relationship between widths of blocks and weave gap

\begin{tabular}{ccc}
\hline Test & Block unit & Weaved gap \\
\cline { 2 - 3 } No. & Width (mm) & Width $(\mathbf{m m})$ \\
\hline 1 & 100 & 0 \\
7 & 40 & 20.08 \\
8 & 30 & 40.06 \\
9 & 20 & 60.04 \\
10 & 10 & 80.01 \\
\hline
\end{tabular}

However, this result could not be directly assessed with respect to the selected ecoperformance criteria, because the width was measured two dimensionally and it was not possible to evaluate the associated volumetricbased efficiency. However, a larger weaved gap is likely to positively affect the eco-performance of the concrete block as a building material for wall construction, as it would improve the thermal comfort of the room that it encloses by creating a patterned opening enabling continuous air movement through the wall. Moreover, the presence of the curvy over-hanged part of the optimized concrete block also creates a patterned shading that would further reduce the transfer of heat through the wall. Therefore, a wall constructed from these optimized concrete blocks could potentially be a passive design strategy for reducing the energy consumption of a building's cooling system in tropical areas, such as Indonesia. However, the scope of this research does not include an assessment of the thermal performance and indoor thermal comfort of the materials; therefore, they are not further discussed in this paper. 


\subsection{Relationship between form properties}

There was a change in the form properties with a decrease in block width, as shown in Table 12.

Table 12. Changes in form properties, according to decrease in block width

\begin{tabular}{|c|c|c|c|c|}
\hline No & $\begin{array}{c}\text { Form } \\
\text { properties }\end{array}$ & Decreased & Increased & Maintained \\
\hline 1 & $\begin{array}{l}\text { Volume of } \\
\text { resting } \\
\text { blocks }\end{array}$ & $\sqrt{ }$ & - & - \\
\hline 2 & $\begin{array}{l}\text { Area of } \\
\text { interlocking } \\
\text { slot }\end{array}$ & $\sqrt{ }$ & - & - \\
\hline 3 & $\begin{array}{l}\text { Volume of } \\
\text { cement } \\
\text { paste as } \\
\text { binding } \\
\text { material }\end{array}$ & $\sqrt{ }$ & - & - \\
\hline 4 & $\begin{array}{l}\text { Width of } \\
\text { weaved gap }\end{array}$ & - & $\sqrt{ }$ & - \\
\hline 5 & $\begin{array}{l}\text { Storage } \\
\text { capacity }\end{array}$ & - & $\sqrt{ }$ & - \\
\hline 6 & $\begin{array}{l}\text { Area of } \\
\text { additional } \\
\text { support }\end{array}$ & - & - & $\sqrt{ }$ \\
\hline 7 & $\begin{array}{l}\text { Volume of } \\
\text { additional } \\
\text { support }\end{array}$ & - & - & $\sqrt{ }$ \\
\hline
\end{tabular}

\section{CONCLUSION}

\subsection{Conclusion}

Form is a necessary product of design because it has both functional and esthetic values. Therefore, to obtain a clear and relevant result, it was necessary to make occasional manual interventions during the optimization process, such as during the preliminary review of the 10 simulation test results. With respect to material consumption, all optimized concrete blocks with widths of $40 \mathrm{~mm}$ or less consumed less than $50 \%$ of the main material and less than $15 \%$ of the auxiliary material, compared with that of conventional concrete blocks. However, only blocks with widths greater than $40 \mathrm{~mm}$ enabled more than $1 \%$ of the total volume of two overlapping blocks to be supported on their interlocking slots. Although precise structural measurements were not conducted in this study, stability was considered when each decision was made, and stability is evidently improved when a greater block volume is supported. Therefore, the optimized form of the new concrete block has a width of $40 \mathrm{~mm}$. In summary, the selected block uses only $43 \%$ of the main material (a mixture of Portland cement, sand, and fine gravel) and $14 \%$ of the auxiliary material (cement paste as the binding material) compared to that of conventional concrete blocks. With respect to space efficiency for storage and transportation processes, $60 \%$ more of these new concrete blocks can fit into a standardized container compared to the conventional concrete block type.

Furthermore, although precise measurements of the compressive strength performance of this concrete block form were not conducted, a nonstructural wall was constructed on a 1:1 scale using the optimized blocks (height and width of $2.5 \mathrm{~m}$ and $3 \mathrm{~m}$, respectively). This wall has been standing for more than 10 years (at the time of writing this paper), and it shows no physical defects (see Figure 10).

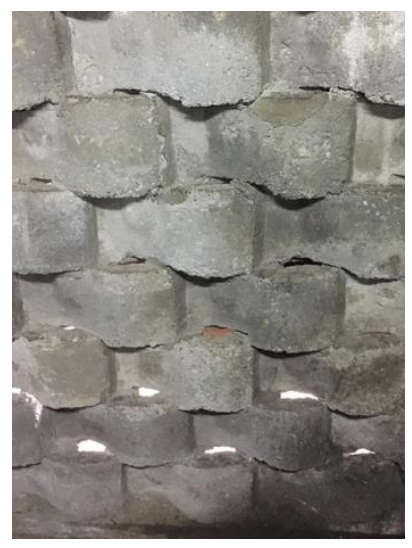

(a) Interior view

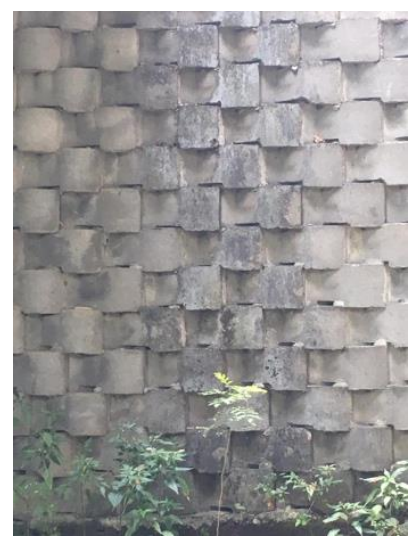

(b) Exterior view

Figure 10: Wall constructed in 2009 using weaved concrete blocks 


\subsection{Research potential and future research plans}

This study represents preliminary research using computational design to determine the optimized concrete block form for use as a building material (with respect to its eco-performance, which is defined as economical, technical, and environmentally friendly performance). The volumetric-based measurement method employed in this research is a simple and practical approach employed in creative design research to enable rapid simulated results. However, it is necessary to conduct further research using a series of structural performance tests to clarify the feasibility of the results obtained here for applying the concrete blocks as structural building elements, as required by standardized regulations. It is also necessary to assess the associated practical and economic benefits by translating the volumetric measurements into local currency.

The findings in this research also suggest other future research potentials, including studying the weaved concrete block as a building element employed in a passive design strategy; particularly with respect to improving indoor thermal comfort. There are several established simulation engines (such as Honeybee and Ladybug) that are currently available for conducting environmental simulations, and Karamba can be used to simulate structural performance. These engines were built in the same environment as the Grasshopper plug-in with Rhinoceros, and they are therefore fully compatible with this research and can support its future development.

Furthermore, regardless of its preliminary nature, this research successfully revealed the potential of using computational parametric design to enable form optimization of a conventional concrete block, with the aim of improving the material's eco-performance. With respect to the generation of creative simulative designs, this research also introduces use of a rapid and simple assessment tool for geometry designers. Finally, the use of this approach is expected to appeal to fellow designers, as it provides the potential of exploring creative geometry, inventing new forms, and optimizing existing materials.

\section{REFERENCES}

Anggreni, M. Y., Sudarsana, I. K., \& Sukrawa, M. (2015). Perilaku Tekan dan Lentur Dinding Pasangan Batako tanpa Plesteran, dengan Plesteran dan dengan Perkuatan Wiremesh. Jurnal Spektran, 3(2), 10-19.

Dan Gavriletea, Marius. (2017). Environmental Impacts of Sand Exploitation. Analysis of Sand Market. Sustainability (Switzerland) 9(7). https://doi.org/10.3390/su9071118

Davis, L., Rippmann, M., Pawlofsky, T., \& Block, P. (2012). Innovative funicular tile vaulting: A prototype vault in Switzerland. Structural Engineer, 90(11), 46-56. Retrieved from www.thestructuralengineer.org

Dinh, T. D., Rezaei, A., Punurai, W., De Laet, L., Mollaert, M., Van Hemelrijck, D., \& Van Paepegem, W. (2016). A shape optimization approach to integrated design and nonlinear analysis of tensioned fabric membrane structures with boundary cables. International Journal of Solids and Structures, $\quad 83$, 114-125. https://doi.org/10.1016/j.jisolstr.2016.01.00 4

Hamid, M. S. A., \& Shafiq, N. (2016). Ecoefficiency index model for reinforced concrete structural design: Malaysia case study. ARPN Journal of Engineering and Applied Sciences, 11(8), 5452-5458.

Hariyadi, A., Fukuda, H., \& Ma, Q. (2017). The effectiveness of the parametric design 'Sudare' blind as external shading for energy efficiency and visibility quality in Jakarta. Architectural Engineering and Design Management, 13(5), 384-403. https://doi.org/10.1080/17452007.2017.129 6811

Hariyadi, A., Suryabrata, J. A., Fitriana, A. N., \& Fukuda, H. (2015). Performance Based Façade Design Study of Department of Public Affair Building Complex in Jakarta Indonesia. Journal of Asian Urban Environment, 7-12.

Harlan, G. Y. W. (2011). Analisis Nilai Guna Ekonomi Dampak Penambangan Pasir Di Kecamatan Tamansari Kabupaten Bogor. Institut Pertanian Bogor. https://doi.org/10.1007/s11525-006-9101-7

International Energy Agency; World Business Council for Sustainable Development. (2009). Cement Technology Roadmap 2009 - Carbon emissions reductions up to 2050. Paris. Retrieved from 
http://www.iipnetwork.org/cementtechnology-roadmap-2009-carbonemissions-reductions-2050

Kim, T., Tae, S., Chae, C., Lee, K., Kim, T., Tae, S., ... Lee, K. (2016). Proposal for the Evaluation of Eco-Efficient Concrete. Sustainability, $8(8), \quad 705$. https://doi.org/10.3390/su8080705

Kobayashi, Y., Kobayashi, H., Hongu, A., \& Sanehira, K. (2005). A Practical Method for Quantifying Eco-efficiency Using Ecodesign Support Tools. Journal of Industrial Ecology, 9(4), 131-144.

Kono, J., Ostermeyer, Y., \& Wallbaum, H. (2018). Trade-Off between the Social and Environmental Performance of Green Concrete: The Case of 6 Countries. Sustainability, 10(7). https://doi.org/10.3390/su10072309

Liang, W., \& Nusryamsi. (2017). Analisa Kuat Tekan Batako dengan Campuran Serbuk Kaca dan Silica Fume. Jurnal Teknik Sipil USU, 6(1).

Linthout, T. (2016). Form-finding and patterning of fabric structures using shape optimization techniques. Universiteit Gent.

Mallisa, H. (2011). Studi Kelayakan Kualitas Batako Hasil Produksi Industri Kecil di Kota Palu. Media Litbang Sulteng, IV(2), 75-82.

Marini, Baja, S., \& Sultan, I. (2014). Penerimaan informasi dampak penambangan pasir bagi kerusakan lingkungan hidup di kalangan penambang pasir ilegal di das jeneberang kabupaten gowa. Jurnal Komunikasi KAREBA， 3(2), 112-118. https://doi.org/10.1080/0812009980872836 5

Messac, A. (2015). Optimization in Practice with MATLAB® for Engineering Students and Professionals. New York: Cambridge University Press. Retrieved from www.cambridge.org/9781107109186

Mohd-Rahim, F., Pirotti, A., Keshavarzsaleh, A., Zainon, N., \& Zakaria, N. (2017). Green Construction Project: A Critical Review of Retrofitting Awarded Green Buildings in Malaysia. Journal Of Design And Built Environment,, 11-26. Retrieved from https://ejournal.um.edu.my/index.php/jdbe/ article/view/10132

Müller, C., Fitriani, E., Halimah, \& Febriana, I. (2006). Training Manual Manufacturing of Concrete Floor/Pavement Tiles and Concrete Hollow Blocks. Jakarta: International Labour Office.
Nordin, N., Ismail, M., \& Mohd Ariffin, A. (2019). Ventilation Blocks: Design Feature In Malaysia Public Schools. Journal Of Design And Built Environment, 19(1), 1-12. Retrieved from https://ejournal.um.edu.my/index.php/jdbe/ article/view/17785

Pottmann, H., Eigensatz, M., Vaxman, A., \& Wallner, J. (2015). Architectural geometry. Computers \& Graphics, 47(47), 145-164.

Rashdi, W. S. S. W. M., \& Embi, M. R. (2016). Analysing Optimum Building form in Relation to Lower Cooling Load. Procedia - Social and Behavioral Sciences, 222, 782-790.

https://doi.org/10.1016/J.SBSPRO.2016.05 .161

Ratti, C., Raydan, D., \& Steemers, K. (2003). Building form and environmental performance: archetypes, analysis and an arid climate. Energy and Buildings, 35(1), 49-59. https://doi.org/10.1016/S03787788(02)00079-8

Safinia, S., \& Alkalbani, A. (2016). Use of Recycled Plastic Water Bottles in Concrete Blocks. Procedia Engineering, 164, 214221.

https://doi.org/10.1016/j.proeng.2016.11.61 2

Winarno, H., \& Pujantara, R. (2015). Pengaruh komposisi bahan pengisi styrofoam pada pembuatan batako mortar semen ditinjau dari karakteristik dan kuat tekan. Jurnal Scientific Pinisi, 1(1), 1-12. Retrieved from

https://www.researchgate.net/publication/3 19623020_PENGARUH_KOMPOSISI_B AHAN_PENGISI_STYROFOAM_PADA _PEMBUATAN_BATAKO_MORTAR_S EMEN_DITINJAU_DARI_KARAKTERI STIK_DAN_KUAT_TEKAN

Yung, S., Norhayati, M., \& Norafida, A. (2018). An Overview of Influencing Factors of Thermal Performance for Open Spaces in the Tropics. Journal Of Design And Built Environment, 18(2), 1-14. Retrieved from https://ejournal.um.edu.my/index.php/jdbe/ article/view/15575

Zhang, A., Bokel, R., van den Dobbelsteen, A., Sun, Y., Huang, Q., \& Zhang, Q. (2017). The effect of geometry parameters on energy and thermal performance of school buildings in cold climates of China. Sustainability (Switzerland), 9(10). https://doi.org/10.3390/su9101708 